\title{
The Statices of the Canaries of the Subsection Nobiles. II.
}

\author{
BY \\ OTTO STAPF, F.L.S. \\ Principal Assistant, Herbarium, Royal Botanic Gardens, Kew.
}

With a Map in the Text.

T $\mathrm{N}$ the first part of this paper (pp. 206-I 2 of the present volume) I have discussed the history and distribution of Statice arborea. I propose now to deal in a similar way with the other Statices of the Nobiles group and sum up their principal characters in a sort of expanded key, reserving the description of the hybrids and a paragraph of a more general character for a third and concluding part.

\section{STATICE MACROPHYLLA.}

This has already been mentioned in the first part of my paper. It is a very distinct and, apart from the variety (?) simuata to which I refer later on, perfectly homogeneous species. Unlike Statice arborea it is still flourishing, although confined to a narrow belt on the north-east coast of the island. It was discovered by Broussonet, who is probably the author of the name Statice macrophylla, although he never published it. The first description, a very short diagnosis, was by Sprengel ${ }^{1}$ in 1825 . He, however, attributed the name to Willdenow and not to Broussonet, as is usually quoted. On the other hand, Steudel ${ }^{2}$ coupled it with Link's name; but neither Willdenow nor Link published anything on the subject. Broussonet's specimens of Statice macrophylla which were in the Montpellier herbarium have been lost. Boissier seems to have seen them, or at least some duplicates distributed by Broussonet, as he quotes them in his monograph of the Plumbagineae, confining himself, however, to the note 'In Teneriffâ, Brouss. ${ }^{3}$ Fortunately an important record concerning them is preserved in F. de Girard's manuscript of a memoir on Statice which was never

${ }^{1}$ Sprengel, Systema Vegetabilium, i, p. 959. $\quad{ }^{2}$ Steudel, Nomenclator Botanicus, ed. II, p. 633 .

${ }^{3}$ Boissier in De Candolle, Prodromus Systematis Naturalis Regni Vegetabilis, xii (1848), p. 637 .

[ Annals of Botany, Vol. XX. No. LXXIX. July, 1906.] 
published, having been forestalled by Boissier's monograph of the Plumbagineae. The manuscript is at present in the Institut Botanique of Montpellier, and Mr. R. N. Rudmose Brown has been good enough to copy for me the passage in question. It runs thus:- 'Hab. (viz. Statice macrophylla) Teneriffe, loco dicto la Puenta de Teno nec non Passo de la Cueva legebat olim Broussonetus.' Punta de Teno is the westernmost point of the island, close to El Freyle where the stunted form of Statice arborea (pp. 208 and 212) still occurs. The other locality I could not trace exactly; but I assume it is a place not far to the east of Cape Hidalgo and above Cueva de Pope, a locality marked in Webb's map of Teneriffe. If this is correct, Paso de la Cueva comes within the area where Statice macrophylla has been observed in more recent times. This is a small belt of rocky coast-land, extending from somewhere near Punta del Viento towards Taganana, and skirting the northern slopes of the Anaga Hills. The first after Broussonet to collect it there were Webb and Berthelot, who in 1828 or 1829 found it ' in montosis herbidis Teneriffae ad vallem de la Goleta et ad montem Bajamar ${ }^{1}$ '. According to Webb's map La Goleta is a small valley extending 3 or $4 \mathrm{~km}$. inland, from a point a little to the east of Punta del Viento, and west of the Mesa de Tejina. L. von Buch has it farther east, and Bolle's ${ }^{2}$ description would also seem to place it east of the Mesa de Tejina and immediately at the western end of the cliffs of the Costa de Bajamar which trends towards Punta del Hidalgo. Possibly Webb's indication of locality refers to one place only, and should read 'La Goleta, ad montem Bajamar' as indeed Bourgeau, who collected the plant in the same place in 1846 , puts it in his label ('in rupestribus herbosis vallis de la Goleta, Bajamar'). Perraudière found it nine years later (March 29, 1855) ' in collibus ad marginem sylvarum Anaga.' This is somewhat vague ; but as Perraudière collected on the 20 th of the same month in 'Anaga. reg. bor. mediâ,' it is practically certain that he meant the northern slopes of the Anaga Hills. Here, east of Punta del Hidalgo, it was observed by Dr. Cabrera (as the Rev. R. P. Murray informs me) near Taborno among rocks in 190I, and according to a note from Dr. Perez, which I owe to the courtesy of the same gentleman, it occurs plentifully in the valley of Afur, at a spot called 'El Tablero,' a sort of headland above the sea, and about $2.5 \mathrm{~km}$. to the west of Taganana. 'Taking Punta del Viento as the western and El Tablero as the eastern end of this area, its length would be about $25 \mathrm{~km}$. To this would, however, as Dr. Perez has just informed me, have to be added an outlying and hitherto unknown station on the high cliffs below the 'Calvary' of Santa Ursula, $5 \mathrm{~km}$. to the north-east of the town

\footnotetext{
1 Webb et Berthelot, Histoire naturelle des Iles Canaries, III, iii, p. I8o. See also their Atlas, tab. ii and iii.

2 Bolle in Zeitschrift für allgemeine Erdkunde, vol. x1 (186I), p. 89.
} 
of Orotava, whilst in Broussonet's locality at Cape Teno we have an indication of a western area where Statice macrophylla has become extinct within the last hundred years.

As to Mann's La Longuera station I have made some suggestions on p. 2II. Dr. Perez has since written that he still thinks Mann meant La Longuera on the Burgado Cove where he also gathered Statice arborea. From Dr. Perez's remarks it would, however, appear that Statice arborea was not wild there, but grown by a peasant near his cottage, and this may also have been the case with Mann's Statice macrophylla.

I have mentioned above a 'variety (?) simuata' of Statice macrophylla. It was described by Boissier ${ }^{1}$ from a specimen received in 1846 by Bourgeau from S. Isidro in Gran Canaria. Through the courtesy of Mr. W. Barbey I have been able to examine the type of this variety. It exactly matches the Teneriffe specimens of Statice macrophylla with the exception of the wider and undulate axial wings. Bourgeau on his label says 'Je ne sais pas s'il est cultivé.' Now, there is in the Kew Herbarium a typical specimen of Statice macrophylla gathered nine years earlier by Kirkman Finlay (a correspondent of Sir William Hooker) in 'Mr. Duthie's grounds' in Gran Canaria. This I take to be from a cultivated plant, and so was in all probability Bourgeau's.

The date of introduction of Statice macrophylla into English horticulture is given as 1824 by Loudon ${ }^{2}$, and the introduction itself is credited to 'Mr. Smith of the Botanic Gardens of Hull' by Sir William Hooker ${ }^{3}$. It seems to have gone out of cultivation long ago, or has, at any rate, become very rare.

\section{StATICE IMBRICATA.}

If Statice arborea exists at present only in a stunted form in the extreme west of Teneriffe, and Statice macrophylla is confined to a narrow belt on the north-east coast, Statice imbricata occupies geographically an intermediate position. It was discovered by Broussonet on El Roque de Garachico, a rock in the sea opposite to the town of Garachico. Here Webb found it again about thirty years later, but it was not made known until 1844 when F. de Girard ${ }^{4}$ described it, taking up Webb's manuscript name. Webb and Berthelot ${ }^{5}$ also observed it 'capris tonsam' on a spot between the Villa Fuente del Cuerbo and the sea, two kilometres to the north-west of the town of Buena Vista. It still was there or in the immediate neighbourhood on sea cliffs in 1855 , when Perraudière collected it. A third locality was discovered by Bourgeau in 1846 , a few kilometres east of

1 Boissier, 1.c. p. $63 \%$

${ }^{2}$ Loudon, Hortus Britannicus (ed. I830), p. I I5.

3 W. Hooker in Eotanical Magazine, tab. 4I 25 (1844).

4 Girard in Annales des Sciences Naturelles, $3^{\text {me }}$ série, ii (1844), p. 330.

5 Webb and Berthelot, 1.c. III, iii, p. I79. 
Tacoronte and known as La Hondura. Here, too, it grew on sea cliffs. La Hondura is some kilometres to the west of the valley of La Goleta as marked in Webb's map, and therefore near the western end of the area of Statice macrophylla. The three little areas inhabited at present by Statice imbricata are therefore from west to east: (I) The sea cliffs of Buena Vista, about 7-8 km. east of Punta de Teno; (2) El Roque de Garachico, about 8-9 km. farther east, and (3) La Hondura near Taraconte, about $30 \mathrm{~km}$. east of Garachico.

Statice imbricata is little known in cultivation. From notes by Don ${ }^{1}$ and Nicholson ${ }^{2}$ it would appear that it was introduced by Webb in 1829 ; but in 1848 it was spoken of and figured in Flore des Serres ${ }^{3}$ as a new introduction, and it was stated that the plants were raised from seeds sent to Europe in 1846 by Webb's collector, which evidently means Bourgeau.

\section{STATICE BRASSICIFOLIA.}

In 1845 Bourgeau discovered two Statices in the islands of Gomera and Hierro respectively, which were described by $W_{e b b}{ }^{4}$ as Statice brassicaefolia (sic) and Statice macroptera. He admitted, however, their great similarity and left it to future explorers to examine whether they were not forms of one species. I may remark at once that specimens collected since then leave no doubt that the plants which Webb described as Statice brassicifolia and Statice macroptera were merely slight variations of what most botanists would consider as one species, differing in stature, pubescence, and width of the axial wings and the subfloral auricles. This view is supported by Perraudière's discovery (1855) of Statice brassicifolia in the locus classicus of Statice macroptera. The differences should, however, not be entirely disregarded, as they seem to be constant, at least within certain limits. Thus specimens raised at Kew from seeds gathered by Bourgeau in Gomera, the locus classicus of Statice brassicifolia, preserved the general facies of that form, which in contradistinction from Statice macroptera is determined mainly by narrower axial wings and subfloral auricles, and by slightly denser pubescence. One of the Kew specimens was figured in the Botanical Magazine (tab. 5162 ) in 1860-that is fifteen years after Bourgeau's discovery-and the figure agrees entirely with Webb's plate of Statice brassicifolia. On the other hand, there is a specimen in the Temperate House at Kew, labelled 'Statice brassicifolia, garden origin,' which combines the wider, deeply-lobed wings of Statice macroptera with the smaller and more pubescent auricles of Statice brassicifolia. This specimen, the history of which I have not been able to trace, may be a descendant of the Gomera

${ }^{1}$ Don, Hortus Cantabrigiensis, $3_{3}$ th ed. (1845), p. 187 .

2 Nicholson, Dictionary of Gardening, iii. p. 492.

${ }_{4} \mathrm{Webb}$ and Berthelot, l. c., III, iii, pp. I8I, 182.

${ }^{3}$ Flore des Serres, iv (I848), Pl. 320-32I. 
plant, figured in 1860 . In those circumstances it will be best to distinguish the two extreme forms as Statice brassicifolia (typica) and Statice brassicifolia, forma macroptera. Neither has been found anywhere outside the islands mentioned, and even there they are confined to a single station in each, namely in Hierro to some steep rocks above Savinosa, on the crater bay of El Golfo on the north side of the island (both forms), and in Gomera to some grassy ledges high up on the gigantic cliff, known as El Risco de las Sulas near Agulo (only the typical form). The Rev. R. P. Murray collected both forms as late as I899, and each in its locus classicus.

I have already referred to the introduction of Statice brassicifolia (typica). The form macroptera was raised by Messrs. Thibaut and Keteleer of Paris, presumably from seeds gathered by Bourgeau in 1845 , and a fine specimen of theirs was figured in Illustration Horticole (Pl. 105) in $185^{5}$. Both are, however, now very rare in cultivation.

\section{Statice PUBERULA.}

We have seen that in Statice arborea and Statice brassicifolia, there is a range of variation great enough to have suggested the presence of distinct species. In Statice puberula this range is still greater, and affects all parts with the exception of the 'spicae' and the ultimate divisions of the inflorescence, both being remarkably uniform throughout. Statice puberula was discovered by Webb and Berthelot ${ }^{1}$ in 1829 . They found it in the island of Lanzarote on the western precipices of the Famara, a basaltic range overhanging the narrow straits of El Rio, which separate Lanzarote from the small island of Graciosa, and also on the other side of El Rio in Graciosa itself. Webb sent seeds of it to his home-place at Godalming, and a plant raised from them was described and figured as Statice puberula, Webb by Lindley ${ }^{2}$ in $183 \mathrm{I}$. Webb's specimens represent an extremely stunted form, scarcely I dm. high, with inflorescences about $4 \mathrm{~cm}$. (or less) across, and dense rosettes of small leaves, the longest blades not much exceeding $3 \mathrm{~cm}$. The leaves are, like the primary axis of the inflorescence, loosely covered with coarse stellate hairs and entire, without a trace of lobing in the decurrent bases. The cultivated specimen figured by Lindley was about twice as high and had a much looser inflorescence, almost $12 \mathrm{~cm}$. across, wingless peduncles, and entire leaf-blades up to $6 \mathrm{~cm}$. long. Another figure of a cultivated specimen of Statice puberula, no doubt of the same origin, and published in the Botanical Magazine (tab. 370I) in I839, represents a plant almost $3 \mathrm{dm}$. high, with an inflorescence of about the same size as in Lindley's plant, but with its primary branches narrowly winged. The blades are up to $4 \mathrm{~cm}$., and the slender petioles up to $6 \mathrm{~cm}$.

\footnotetext{
${ }_{1} \mathrm{Webb}$ and Berthelot, 1. c., III, pp. 27,28 , and III, ii, p. I 78 .

${ }^{2}$ Lindley in Botanical Register, tab. 1450.
} 
long, and in some of the blades there is an indication of lobing. A specimen cut from a plant in cultivation at Kew in Sir William Hooker's time is almost a complete match of the figure in the Botanical Magazine, which was drawn from a plant grown in Edinburgh. Another specimen from a plant at Kew, but of recent cultivation is also very similar to the latter, but the lobing of the blade is more pronounced and extends to the decurrent base, and I might add, the blades are somewhat larger (up to 5 by $3 \mathrm{~cm}$.). This deviation from the original type when under cultivation has a complete parallel in a specimen collected by Lowe (in $185^{8}$ ) on the 'cliff above the Salinas, Haria,' which is evidently the same locality as Webb's and Berthelot's on the Famara, the Salinas being situated on El Rio, close under the cliffs of the Famara. One of the leaves shows distinct lobing at the base, and one or the other of the primary branches of the panicle is narrowly winged. On the other hand, Low also collected with it a barren rosette agreeing exactly with Webb's originals from Graciosa. This marks, so far as we can safely say at present, the range of variation such as may be considered as the direct result of external conditions, and it was necessary to mention those details in order to appreciate the position of another form from the same locality, and generally admitted as a distinct species, viz. Statice Bourgaci. Its history is briefly this. In I 845 Bourgeau collected in the island of Lanzarote, in a place 'Los tanques de Famara,' a plant which he distributed as Statice puberula (No. 335). In the following year he issued it again (No. 564), but this rime as Statice Bourgeaci (sic), Webb, and with the indication ' in rupestribus Famara.' The two plants are absolutely identical, and differ from the original Statice puberula in being $4-5 \mathrm{dm}$. high, and correspondingly more robust, and in having very much larger leaves, the blades measuring up to $10 \mathrm{~cm}$. by $8 \mathrm{~cm}$., and varying from ovate to suborbicular or elliptic-oblong with a suddenly contracted, decurrent, and usually sinuately-lobed base. The primary axis, and some of the primary branches of the inflorescence, are narrowly and unequally winged. The indumentum is of the same nature as in Webb's Statice puberula, and the flowers also agree perfectly with those of that plant. Boissier gave a full description of Statice Bourgaci, Webb, in $1848^{1}$, based on Bourgeau's No. 564, whilst he refers, curiously enough, No. 335 to Statice puberula. He describes the leaves much as I have done in the preceding lines, and adds that the flowers are twice as large as those of Statice puberula. Neither this statement nor the indication of certain minor differences in the characters of the bracts are borne out by the material at my disposal. Statice Bourgaei was raised at Kew from seeds communicated by Bourgeau. It flowered here for the first time in 1859 . A specimen cut from it in 1861 might be described as a reduced and glabrescent edition of Bourgeau's No. 564, the largest blade measuring only 10 by $5 \mathrm{~cm}$. To judge, however, ${ }^{1}$ Boissier, 1. c., p. 638 . 
from the figure published in Flore de Serres (tab. 2292) in 1877 , and drawn from a plant received from Kew, the Kew stock of Statice Bourgaei attained subsequently quite the dimensions of Bourgeau's herbarium specimens distributed under No. 564, and the same may be said of a plant still in cultivation at Kew.

During the last few years Kew received from Dr. Perez a fine suite of specimens which were put down either as Statice Bourgaei or as nearly related to it. They may be grouped in four sets.

Set I marked 'Statice Bourgaci (original plant from Famara)' agrees with Bourgeau's Nos. 335 and 564 , except in so far as the specimens are still more robust, and have all the leaves broad-ovate with a suddenly contracted, decurrent, and mostly (not always) lobed base, the blades measuring up to 13 by $10 \mathrm{~cm}$., excluding the decurrent base.

Set 2 represents a plant which-if I interpret Dr. Perez's note correctly-was originally received from Lanzarote, and had been in cultivation with Dr. Perez for how long I cannot say, but apparently not for more than one or two years. The specimens of this set have much enlarged inflorescences, up to $25 \mathrm{~cm}$. high (from the lowest branch) and as broad, with more conspicuous but irregular wings, and less hairy almost orbicular blades (about IO-II cm. in diameter), and with more or less decurrent and usually sinuately-lobed bases.

Set 3 was raised from seeds received from Ye, a locality, according to Dr. Perez's description, evidently not very far from the Salinas, and half an hour from the seashore. The blades are still more glabrescent than in set 2, have entire decurrent bases, and also show in their upper parts only traces of lobing, or even not as much as that, whilst the wings of the primary axis of the inflorescence vary from $\mathrm{I} \cdot 5^{-1} 3 \mathrm{~mm}$. in width.

Set 4 has magnificent large inflorescences and leaves like those of set 2 , but quite glabrous, and axial wings varying from $2-8 \mathrm{~mm}$. width. It originated from seeds, also gathered in Lanzarote, but where is not stated.

In spite of the considerable diversity exhibited by the plants of Dr. Perez's four sets, I do not hesitate to consider them merely as individual variations of Statice Bourgaei, some characters of which have probably become particularly accentuated under the influence of cultivation.

I have already pointed out that Webb and Berthelot's and Lowe's stations of the typical Statice puberula are identical, and they cover evidently a very small area. 'Los Tanques' I have not found in any map, but it is very likely in the neighbourhood of the Salinas. In any case it is in the Famara, and I believe I am right in tracing all the plants of Dr. Perez's four sets to the same district, so that the area inhabited by Statice puberula and Statice Bourgaei covers a small piece of rocky coast on the south side of El Rio, whilst an equally small or still smaller strip of land on the northern side of El Rio harbours exclusively the dwarf Statice puberula. 
We find then here in the north of Lanzarote, and in the adjoining Graciosa, within a very small area-it might be almost said in the same locality-two types of a Statice, indistinguishable in their floral characters, and also connected with each other (and at the same time distinguished from all their allies of the Nobiles group) by the nature of their indumentum, but otherwise fairly well marked. They each have its own range of variation, though on parallel lines, and they are both plastic to a certain degree. Considering all that, it seems to stand to reason to treat them as varieties of one species. For this the name Statice puberula would have to stand, whilst the varieties might be distinguished as var. typica and var. Bourgaei. The differentiation of Statice puberula into two forms is comparable to that of Statice arborea and Statice brassicifolia, but much more pronounced. This I have indicated by introducing the term 'variety' instead of 'form' into the names. Whilst in the case of Statice arborea and Statice brassicifolia it is impossible to say which of the two forms in each case is the older, it seems to be quite evident that Statice puberula var. Bourgaei approaches much more closely its allies of the Nobiles section than Statice puberula var. typica, which betrays in every one of its vegetative characters its specialization in the direction of adaptation to the conditions of an excessively arid region. There is, as far as I am aware, no record of a former extension of the area of Statice puberula, but there can be no doubt that its present stations on El Rio are only the remnant of a much larger area.

\section{STATICE PREAUXII.}

Under this name $W e b b^{1}$ described a species, specimens of which had been sent by Despréaux from Gran Canaria ('a Canariâ misit'). Boissier ${ }^{2}$ puts it more definitely, so as to imply that it was a native of Gran Canaria ('In insula Canariâ. Despréaux!') According to Lasègue ${ }^{3}$, Dr. J.M. Despréaux resided for a considerable time in Gran Canaria, but in 1835 also visited Teneriffe, Fuerteventura, Lanzarote, Hierro, and Gomera. But there is some uncertainty about the exact origin of Despréaux's Canarian plants, and $\mathrm{Webb}^{4}$ denies that he ever was in Hierro and Gomera, although he may have received plants from there. It may well be that he sent the original specimens of Statice Preauxii from Gran Canaria, but had originally obtained them from somewhere else. In any case it has not been observed by any one else in Gran Canaria. Webb compares it with Statice arborea, Boissier places it with Statice puberula and his Statice Bourgaci. I have not seen it, but excepting that the leaves are said to be very coriaceous and compared by Boissier to those of Aegialitis, there is nothing in the description either of Webb or of Boissier to separate it from the polymorphous Statice

\footnotetext{
$1 \mathrm{Webb}$ and Berthelot, 1. c., III, iii, p. I8I.

2 Boissier, 1. c., p. 638.

${ }^{3}$ Lasègue, Musée Botanique de M. B. Delessert, p. I87.

${ }_{4}$ Webb and Berthelot, 1. c., III, iii, p. 182 , fontnote.
} 
puberula (sensu latiore). In the circumstances, however, I prefer to leave open the question as to origin and position of this species.

I insert here a sketch-map of the Canarian Archipelago, which may serve as a summary of our present knowledge of the distribution of the Statices of the Nobiles group.
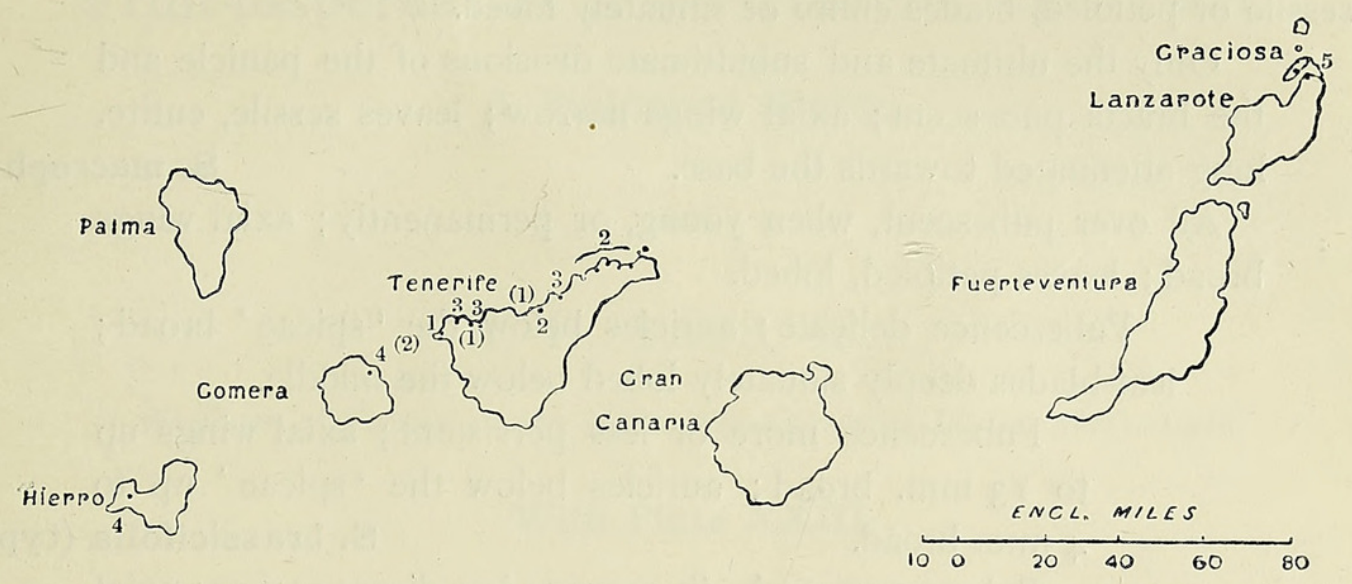

Distribution of the Statices of the Nobiles group-

I. Statice arborea. 2. Statice macrophylla. 4. Statice lrassicifolia.

5. Statice puberula.

3. Statice imbricata.

The figures in brackets mark stations from which the species has disappeared in recent times.

As there exist excellent figures and fairly good descriptions of all the species mentioned above (with the exception of the dubious Statice Preanxii), I do not consider it necessary to describe them over again in extenso; but I thought it might be useful to add short diagnoses put together in the form of a key, a sort of condensed descriptions fractionnées et classées $^{1}$. They would bring out the salient characters of the species, and at the same time facilitate identification.

\section{KEY.}

Ultimate divisions of the panicle winged, with the wings widened upwards and produced into auricles; pubescence, if any, uniform.

Glabrous or nearly so (only the ultimate or subultimate divisions of the panicle sometimes sparingly pubescent); primary axis of the inflorescence and its primary divisions wingless or very narrowly winged; auricles below the 'spicae' usually produced into fine, often sickleshaped points; inner bracts with distinct laterally-compressed, abruptlyending keel and narrow scarious margin; leaves distinctly petioled, blades often slightly undulate and shallowly sinuate at the decurrent base.

Bare main stem several feet high; leaves to over $30 \mathrm{~cm}$. by I $3 \mathrm{~cm}$. S. arborea (typica).

Bare main stem very short, branches from the ground or almost so ; leaves rarely over $10 \mathrm{~cm}$. by $5 \mathrm{~cm}$.

S. arborea f. frutescens.

$$
1 \text { De Candolle, Phytographie, p. } 68 .
$$


Pubescence extending over the whole plant, or confined to the ultimate divisions of the panicle and the bracts; primary axis of the inflorescence and its primary divisions winged; auricles below the 'spicae' obtuse, rarely with a short broad acute point; inner bracts rounded on the back, and with a conspicuous crisp blue frill; leaves sessile or petioled, blades entire or sinuately lobed.

Only the ultimate and subultimate divisions of the panicle and the bracts pubescent; axial wings narrow; leaves sessile, entire, long attenuated towards the base.

S. macrophylla.

All over pubescent, when young, or permanently; axial wings broad; leaves petioled, lobed.

Pubescence delicate; auricles below the 'spicae' broad; leaf-blades deeply sinuately lobed below the middle.

Pubescence more or less persistent; axial wings up to I $3 \mathrm{~mm}$. broad; auricles below the 'spicae' up to $4 \mathrm{~mm}$. broad.

S. brassicifolia (typica).

Pubescence gradually more or less disappearing; axial wings up to $25 \mathrm{~mm}$. broad; auricles below the 'spicae' up to $9 \mathrm{~mm}$. broad.

S. brassicifolia f. macroptera.

Pubescence dense, velvety, persistent; auricles below the 'spicae' small ; leaf-blades runcinately pinnatipartite, lobes obovate to obliquely reniform, overlapping, decreasing basewards.

S. imbricata.

Ultimate divisions of the panicle not winged or auricled; leaves with coarse, stellate or fascicled hairs, rarely glabrous; inflorescence uniformly pubescent in the upper part, with intermixed coarse fascicled hairs on the primary axis and main branches.

With the small inflorescences up to I $\mathrm{dm}$. high; leaf-blades in dense rosettes up to 3 (rarely to 6 ) $\mathrm{cm}$. long, not, or very obscurely, lobed.

S. puberula (typica).

With the large inflorescences up to $5 \mathrm{dm}$. high; leaf-blades in loose rosettes, up to I I $\mathrm{cm}$. long, the decurrent base usually lobed.

S. puberula var. Bourgaei. 


\section{$2 \mathrm{BHL}$ Biodiversity Heritage Library}

Stapf, O. 1906. "The statices of the canaries of the subsection nobiles. II." Annals of botany 20, 301-310.

https://doi.org/10.1093/oxfordjournals.aob.a089101.

View This Item Online: https://www.biodiversitylibrary.org/item/234848

DOI: https://doi.org/10.1093/oxfordjournals.aob.a089101

Permalink: https://www.biodiversitylibrary.org/partpdf/318841

\section{Holding Institution}

Smithsonian Libraries

\section{Sponsored by}

Biodiversity Heritage Library

\section{Copyright \& Reuse}

Copyright Status: Not in copyright. The BHL knows of no copyright restrictions on this item.

This document was created from content at the Biodiversity Heritage Library, the world's largest open access digital library for biodiversity literature and archives. Visit BHL at https://www.biodiversitylibrary.org. 